Vladimir Njegomir ${ }^{1}$

UDC 368:005.334

Miroslav Miškić ${ }^{2}$

\title{
INSURANCE COMPANIES' FINANCIAL INTERMEDIATION ${ }^{3}$
}

\begin{abstract}
Due to the transformation of the social-economic system and the affirmation of the capital market in countries that are currently in transition, including those countries in the Balkan region, the issues of the concept, role, importance, method of functioning, efficient portfolio management, and efficient management of institutional investors are gaining significance and increased attention. Insurance companies are contributing to the process of privatization and development of the market economy, as well as to efficient capital allocation, and this is especially important for countries lacking money and capital, which is precisely the case with the economies of the countries in the region. The goal of this research is to examine the role of the insurance companies as mobilizers of savings and of investors, as well as to explore the function of these saving methods in achieving economic development. The paper shall describe the structure of the financial system, the role played by insurance companies, the process of institutionalized financial saving, the importance of insurance companies in financial intermediation, the measuring of returns and risks
\end{abstract}

\footnotetext{
${ }^{1}$ Associate professor, Faculty of Law and Business Studies dr Lazar Vrtakić, Novi Sad, Union University, Belgrade, email: vnjegomir@flv.edu.rs

${ }^{2}$ Assistant Professor, Faculty of Technical Sciences, University of Novi Sad, email: miroslav.miskic@outlook.com

${ }^{3}$ This is an Open Access article distributed under the terms of the Creative Commons Attribution License (http://creativecommons.org/licenses/by/4.0/), which permits unrestricted use, distribution, and reproduction in any medium, provided the original work is properly cited.
} 
of investments of insurance companies, and the costs of the investment risk of the insurer, as well as comment on the importance and characteristics of institutional investing.

KeY WORDS: financial intermediation, insurance companies, investments

\section{INTRODUCTION}

The insurance business as a mobilizer of savings in the form of institutional investing is an integral part of the financial services sector of a national economy and it has an important influence on development of the financial market and performance of the entire economy. On the other side, the development of the economy and financial market has a strong influence on the development of the insurance sector (Miškić, 2015). This activity is represented by those insurance and reinsurance companies which have a great concentration of money, generally amassed in the form of small investments and individual premiums from the insured and the equities of the shareholders and which is then invested in various forms - most frequently in monetary and similar financial vehicles, but also in real property. Through the mobilization and investment of available and fragmented funds, the insurance sector fosters economic development and the creation of social well-being, while also achieving its primary objective of maximizing profit with certain degree of risk tolerance; this is done not only in the interest of insurance and reinsurance companies, but also of the insured, the shareholders, the economy, and society as a whole.

The paper shall describe the structure of the financial system, the role played by insurance companies, the process of institutionalized financial saving, the importance of insurance companies in financial intermediation, the measuring of returns and risks of investments of insurance companies, and the costs of the investment risk of the insurer, as well as comment on the importance and characteristics of institutional investing. 


\section{STRUCTURE OF THE FINANCIAL SYSTEM AND ROLE OF THE INSURANCE COMPANIES}

In order to illustrate the structure and functioning of financial mechanisms, and understanding of the sector allocation of cash accumulation and financial savings is necessary. Cash accumulation from the macro perspective represents the difference between the actual cash revenues and expenses for spending, while from the micro point of view it represents the difference between the revenues gained from goods and services and the costs derived from operating expenses, taxes, etc. Financial savings represent the difference between cash accumulation and expenses for investments in fixed and operating assets; utilizing these relations, we can speak about a surplus or shortage of financial savings.

A modern financial system enables the rational and efficient utilization of resources and encourages sectors with a surplus of financial savings (such as the financial sector and the general population) to invest their money in order to create wealth. The purpose is to mobilize the savings of millions of people and by means of the market mechanism to invest it in vehicles that contribute to the growth of economic activities, thus promoting faster economic growth. This transfer of savings from those in a savings positive position to subjects in a savings deficiency position is shown in Figure 1, as is the position of insurance companies in the financial system.

Figure 1. Structure of the financial system and the position of insurance companies [18]

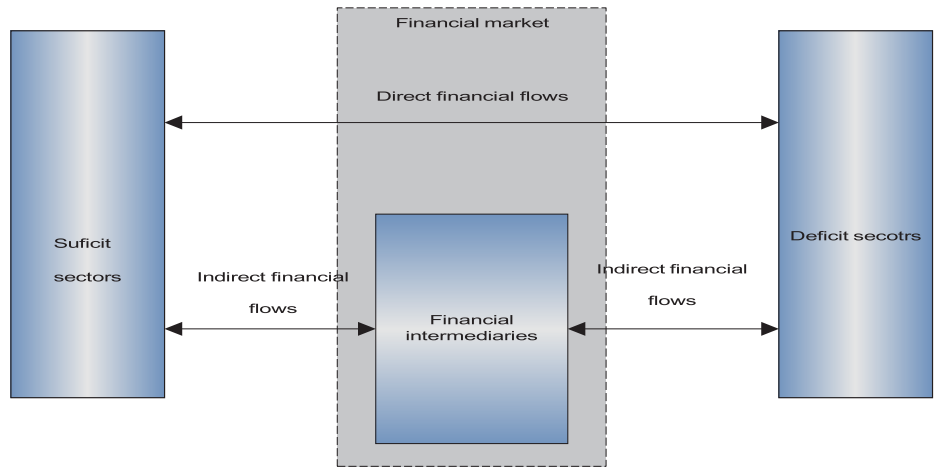

Source: Njegomir $(2011,359)$ 
The Figure clearly shows the elements of the financial system: 1) financial market, 2) financial instruments, 3) financial flows, and 4) financial institutions. The improvement of the economic efficiency of the savings surplus investments, or the accumulated small amounts of insured individuals and their investment by means of investment activities of the insurance companies, are the crucial element behind the existence of private insurance companies (Dorfman, 2008: 75).

\section{INSTITUTIONALIZATION OF FINANCIAL SAVINGS}

The institutional investors, with their scope of business, decisively affect the more rapid development of the capital market in developed market economies, especially in the English-speaking countries, increasing the variety of available investment forms, initiating their creation, and fostering trading through financial instruments, enabling the development of the entire economy in these countries in the process. (Miškić, 2013). One of the key indicators of the growing impact of institutional investors on financial markets is the structure of ownership over securities, a structure which has significantly shifted in favor of institutional investors, as demonstrated in Table 1, with Great Britain serving as the example.

Table 1. Structure of shares ownership in \% in Great Britain for the period 1963-2014.

\begin{tabular}{|c|c|c|c|c|c|c|c|c|c|c|c|}
\hline Sector & 1963. & 1975. & 989. & 997. & 000. & 004. & 006. & 008.2 & 010. & 012.2 & 014. \\
\hline Rest of the world & 7 & 5,6 & 12,8 & 24 & 32,4 & 32,6 & 40,0 & 41,5 & 43,4 & $\mid \overline{53,6}$ & 53,8 \\
\hline Insurance companies & 10 & 15,9 & 18,6 & 23,5 & 21 & 17,2 & 14,7 & 13,4 & 8,8 & 6,2 & 5,9 \\
\hline Pension funds & 6,4 & 16,8 & 30,6 & 22,1 & 17,7 & 15,7 & 12,7 & 12,8 & 5,6 & 4,7 & 3,0 \\
\hline Individual investors & 54 & 37,5 & 20,6 & 16,5 & 16 & 14,1 & 12,8 & 10,2 & 10,2 & 6,6 & 7,1 \\
\hline Open investment funds & 1,3 & 4,1 & 5,9 & 6,7 & 1,7 & 1,9 & 1,6 & 1,8 & 2,1 & 1,7 & 1,8 \\
\hline Closed investment funds & & & 1,6 & 1,9 & 2,1 & 3,3 & 2,4 & 1,9 & 8,8 & 9,5 & 9,0 \\
\hline Other financial institutions & 11,31 & 10,51 & 1,1 & 2 & 4,6 & 10,7 & 9,6 & 10,0 & 12,3 & 6,6 & 7,1 \\
\hline Charities, churches, etc. & 2,1 & 2,3 & 2,3 & 1,9 & 1,4 & 1,1 & 0,9 & 0,8 & 0,8 & 0,6 & 1,2 \\
\hline Private companies & 5,1 & 3 & 3,8 & 1,2 & 1,5 & 0,6 & 1,8 & 3,0 & 2,3 & 2,4 & 2,0 \\
\hline Public sector & 1,5 & 3,6 & 2 & 0,1 & - & 0,1 & 0,1 & 1,1 & 3,1 & 2,7 & 2,9 \\
\hline Banks & 1,3 & 0,7 & 0,7 & 0,1 & 1,4 & 2,7 & 3,4 & 3,5 & 2,5 & 1,9 & 1,4 \\
\hline
\end{tabular}

Source: Share ownership (2005); Share ownership survey (2010) and Ownership of UK Quoted Shares (2014). 
Factors which have contributed to the strong capital growth of these financial institutions are: changes in the preferences of the population in regard to investment of their financial savings, the ageing of the population and the weakening of pay-as-you-go financing, technological progress and the application of information and telecommunication technologies, the deregulation of financial services, the suspension of limitations in free capital movement, the process of withdrawals by banks from the intermediation sphere, the special tax treatment of pension funds and life insurance, higher rates of returns on the saving products of institutional investors, and legal regulations, which, in some states, explicitly favor certain institutional investors. (Bloommestein \& Funke, 1998: 15)

\section{IMPORTANCE OF THE FINANCIAL INTERMEDIATION OF INSURANCE COMPANIES}

The importance of financial intermediation will be explained through an analysis of the role of insurance companies as institutional investors in the developed countries of the European Union and the USA before proceeding onto an examination of the specificities of financial intermediation in Serbia, Croatia, and Slovenia.

Insurance companies have stood as the largest institutional investors in the European Union for some time. As an illustration of this point, the total volume of the investment in 2013 by insurance companies amounted to over 8,527 billion Euros, which represents approximately $59 \%$ of the total gross domestic product of the combined European Union states. (IE, 2015) Insurance companies in Europe own approximately $25 \%$ of all government bonds issued by European Union member states, approximately $21 \%$ of all European corporate bonds, and hold a significant portion of all quoted stocks and of property, such as that related to infrastructure. (IE, 2015)

Insurance companies in Europe, according to data from 2011, owned approximately $11 \%$ of bank debt in the Eurozone, $24 \%$ of the public debt of European Union states, and 18\% of total shares and 14\% of mortgage bonds in the same market. Moreover, insurance companies 
invested into infrastructure projects in amounts totaling around EUR 11.7 billion and into direct loans to small and mid-sized companies at a value of approximately EUR 14.1 billion, while investing approximately EUR 18.9 billion into (unlisted) private shares (unlisted).

European insurance companies now manage approximately $12 \%$ of total global financial property. About $62 \%$ of the total investment of insurance companies from the European Union belongs to insurance companies from Great Britain, France, and Germany. (IE, 2014) Figure 2 shows the percentages of value held by insurers and other institutional investors in Europe in 2011.

Figure 2. Insurance companies are the biggest institutional investors in Europe [20]

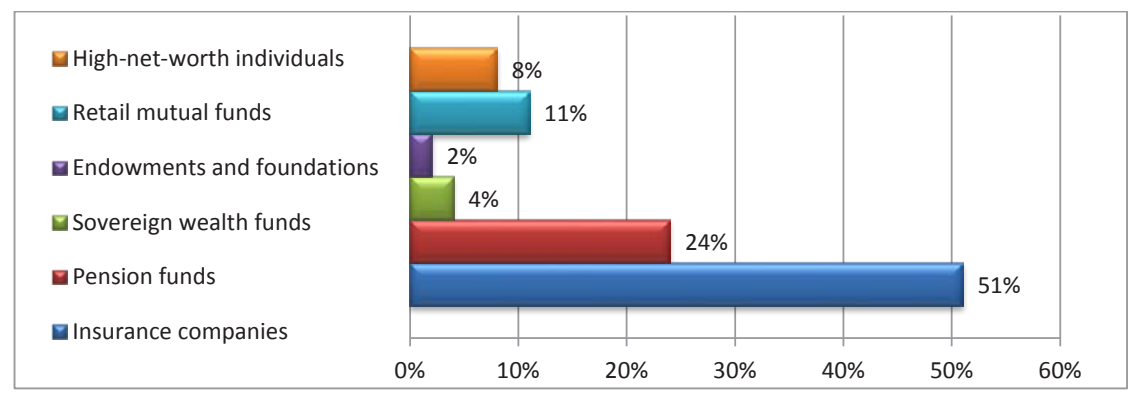

Source: IE (2013: 12)

The most important economic contribution of the insurance industry in the USA is the significant investments made by its network of companies into the financial market. In 2014, U.S. insurance companies invested approximately 5.1 trillions USD in total. Non-life insurance companies invested 1.5 trillions of this total, while life insurance companies invested 3.6 trillions. The greatest portion of funds owned by life and non-life insurance companies is invested into bonds. Life insurers invested $74 \%$ of life insurance polices and non-life insurers $61 \%$. Investments of non-life insurance companies in local government bonds alone amounted to 321.7 billion USD. Life insurers also invest significantly in the more predictable corporate shares, as well as in corporate and foreign bonds. The total amount of these investments in 2014 was 1.8 trillions and 2.3 trillions USD, respectively. 
In Serbia and the surrounding region, the situation is quite different; i.e., the role of institutional investors is significantly smaller when compared to developed countries like the USA and those in the EU.

In 2014, the long-term financial investments of all insurance companies in Serbia amounted to RSD 53.78 billion. Held-to-maturity investments made up $29.82 \%$ of the total investments. By far the greatest percentage of these investments, i.e. $95.59 \%$, consisted of debt securities with a fixed return, while the remainder was comprised of all other securities.(NBS, 2015) A detailed structure of the investments of insurance companies in Serbia and other countries in the region will be present below.

The trends of investments by insurance companies in Croatia are shown in Table 2. The table shows the volume of investments of insurance companies by year from 2007 to 2013. It is evident that the investments of insurance companies were increasing from year to year, despite the global financial crisis, which also affected the insurance business in the region, as well as the general economies of the corresponding countries.

Table 2. Investments of insurance companies in Croatia from 2007 to 2013 (in EUR mil.)

\begin{tabular}{|lrrrrrrr|} 
Year & 2007 & 2008 & 2009 & 2010 & 2011 & 2012 & 2013 \\
\hline Investments & 2.642 & 2.630 & 2.905 & 3.245 & 3.394 & 3.590 & 3.649
\end{tabular}

Source: Insurance Europe, respective years

Of the former SFRY (the Socialist Federal Republic of Yugoslavia) countries, the most developed insurance market, as well as the most highly-developed overall economy, is in Slovenia, the first former SFRY state to become a full EU member. The investments of insurance companies in Slovenia are shown in Table 3. 
Table 3. Investments of insurance companies in Slovenia from 2007 to 2013 (in EUR mil.)

\begin{tabular}{lrrrrrrr|} 
Year & 2007 & 2008 & 2009 & 2010 & 2011 & 2012 & 2013 \\
Invest- & 5.847 & 4.698 & 5.038 & 5.031 & 4.212 & 4.431 & 4.444 \\
ments & & & & & & & \\
\hline
\end{tabular}

Source: Insurance Europe, respective years

Table 3 indicates that the investments of insurance companies in Slovenia were negatively affected by the financial crisis. A sudden decrease of around $20 \%$ of the investment volume from 2007 to 2008 is apparent. Also, it is evident that even at the end of the observed period there was no clear indication towards returning to the total volume of investments the insurance companies exhibited before the crisis.

\section{MEASURING THE YIELDS AND RISKS OF INSURANCE COMPANY INVESTMENTS}

Yields and risks are mutually connected. Short term government bonds have the lowest yield, but they also maintain the lowest risk, while stocks, whose purchase gives the investor a direct share in the ownership, and thereby the risk, of a company, often generate the highest yields, yet also produce the highest risk. (Vasiljević, 2002: 60) A practical way to summarize the events and corresponding probabilities in a certain time period is to employ a probability distribution indicator; i.e., lists of the probability distribution of events which could occur and the corresponding probability of the occurrence of each individual event. The expected yield is in essence equal to the average of all yields which can be realized, weighted with the probability of realization. Average or expected value is obtained by multiplying each individual yield amount by the corresponding probability of the realization of each yield. The obtained values are then summed:

$$
\mu=\operatorname{EV}(\mathrm{X})=\Sigma \mathrm{xiP}(\mathrm{xi})
$$

where $x i$ is the yield amount and $P(x i)$ the probability of the realization of the individual yield amount. 
The statistical measure of dispersion most commonly used as the measure for investment risk is standard deviation. If the standard deviation is equal to zero, then investment risk does not exist. Standard deviation is calculated through the calculation of variance. Standard deviation represents the square root of the variance. The variance is the sum of the squares of dispersions around an expected yield, weighted with the probability of occurrence. The variance is the measure which represents the sum of the squares of the deviations between the possible results and the expected, calculated mean values, multiplied by the probability of individual results:

$$
\sigma_{X}^{2}=\Sigma P_{i}\left(x_{i}-E V(X)\right)^{2}
$$

where $P i$ is the probability of individual results, $x i$ the individual amounts of losses, and $\mathrm{EV}(\mathrm{X})$ the calculated mean, i.e., the expected value of the yield.

Taking into account that the variance represents a graded indicator, standard deviation indicators are used. Standard deviation represents the square root of the variance and the square root needs to be calculated in order for the measure of central tendency and dispersion to be the same size. So, the measure of standard deviation is:

$$
\sigma_{X}=\sqrt{\sigma_{X}{ }^{2}}=\sqrt{\Sigma P_{i}\left(x_{i}-E V(X)\right)^{2}}
$$

The distribution of the mean deviations of samples does not depend on the distribution of the population (basic set), provided that the $n$ (number of units in the sample) is large enough.

\section{THE COSTS OF THE INVESTMENT RISK OF INSURANCE COMPANIES}

One of the key dilemmas facing investors is determining the exact value of the costs of a risk, i.e., the value of how much the certain risk of an investment in the market portfolio stands against the increased yield when compared with holding on to non-risk financial 
instruments, as well as assessing which combination of risky and nonrisk instruments would bring about the optimal yield. Usually, in response to the question of risk price, the CAPM model is used (Capital Asset Pricing Model). Specifically, the Capital Asset Pricing Model is used with the aim of determining the required yield rate for taking on additional risk in the portfolio.

CAPM presumes as optimal a portfolio in which an investor with risk aversion combines a market portfolio with a non-risk portfolio. In such a scenario, what the investors with risk aversion seek is that the yield of the market portfolio, E (rM), is greater than the yield of the non-risk financial instrument, $(\mathrm{rF})$, by the amount of the premium, which corresponds to the risk of holding the market portfolio. The difference between the expected yield of the market portfolio and the non-risk yield is called the market price of risk (Vasiljević, 2002: 72):

$$
E\left(r_{M}\right)-r_{F}
$$

The price of risk of each individual financial instrument in the market portfolio is conditioned with the ratio of risk of each financial instrument (measured by its sensitivity) and the risk of the market portfolio. The equation of the expected yield of a financial instrument $\mathrm{A}$, corrected by the risk of that instrument, is (Vasiljević, 2002: 72):

$$
E\left(r_{A}\right)=r_{F}+\left[E\left(r_{M}\right)-r_{F}\right] \beta_{A}
$$

where: $E\left(r_{A}\right)$ is the expected yield of financial instrument $A$ and $\beta_{A}$ is the coefficient of yield sensitivity of financial instrument $A$ in relation to the total yield of the portfolio.

The price of risk of the financial instrument is equal to the product of the beta coefficient of that instrument and the yield of the market portfolio. 


\section{IMPORTANCE AND CHARACTERISTICS OF THE COORDINATED MANAGEMENT OF INSURANCE BUSINESS AND INVESTMENTS OF INSURANCE COMPANIES}

The main objective of the coordinated management of assets and liabilities is to estimate the risk and to develop optimal investment strategies which will enable the maximization of yields on a given level of risk.

Specifically, what is sought is the realization of the optimal ratio risk/yield, which is achieved at a given level of risk when it is not possible to further increase the yield without having the level of risk increased. (Davis \& Steil, 2001: 52)

If an unforeseen circumstance occurs and the insurer has to pay insurance benefits or sums insured, he will have to "sell" his investments below their real value and for him the loss will be created on the side of assets, i.e., property, as well as on the side of liabilities. In light of this, it is extremely important that investments are matching liabilities, so that the maturity of liabilities can be matched with them; i.e., the investments are matching the corresponding nature of the liabilities of an insurance company. This is achieved through creating a balance of investments against the liabilities of the insurance company. Here, three forms for achieving this balance should be mentioned:

\section{1. currency matching, \\ 2. time matching, \\ 3. inflation matching.}

Once the investments are matching the liabilities, as described earlier, it is possible to additionally affect the decrease of risk from the peril of a property not matching its liabilities by diversifying the investment portfolio with a selection of various forms of property which represent similar investments. ((Booth et al., 1998: 32) 


\section{CONCLUSION}

The research exhibited in the paper clearly demonstrates the role of insurance companies in the financial intermediation of financial markets. Insurance companies play a significant part in the financial intermediation between the savings deficiency and savings surplus sectors of the economy. The importance of the insurance companies as financial intermediaries, i.e., institutional investors, is of particular significance in the developed countries of the European Union and the USA. The comparative analyses contained in this paper highlight critical differences in the degree of institutional investing of insurance companies in Serbia, and other countries of the region, compared to more developed countries. Considering the great importance that such institutional investing by the insurance companies has in regard to economic development, all countries of the region should find methods for improvement in this sector. In regard to Serbia, the best approach within the unchanged available earnings of the population would be the abolishment of tax on life insurance premiums. Life insurance has the character of long term savings and thus they represent the best quality assets for investment on financial markets. Moreover, insurance companies themselves must carefully monitor the analysis of yields and risks so as to properly set the price of risk and match properties with liabilities appropriately, i.e., investments with liabilities, in order to facilitate uninterrupted development, which is of primary significance not only for insurance companies and the insured, but for the country as well.

\section{REFERENCES}

Njegomir, V., (2011). Osiguranje, Novi Sad: Ortomedics book.

Miškić, M., (2015), “The Place and Role of the Insurance Industry in Strengthening of the Real Sector", Collection of papers, Tenth International symposium on Corporate Governance: Small Economies and New Paradigms of Economic Growth, Banja Vrucica.

Dorfman, M.S., (2008). Introduction to Risk Management and Insurance, Upper Saddle River, NJ.: Pearson International Edition.

Miškić, M., (2013). "Insurance Companies as Institutional Investors," in Kočović J., Jovanović-Gavrilović B., Radović-Marković M. (eds.) Product Specifics on the Markets of Insurance and Reinsurance, Ekonomski fakultet u Beogradu, p. $353-370$ 
Share Ownership (2005). A Report on the Ownership of Shares as of the $31^{\text {st }}$ of December, 2004, Office for National Statistics, 2005.

Share ownership survey (2010). Office for National Statistics, 27th January 2010.

Ownership of UK Quoted Shares (2014). Office for National Statistics, 2nd September 2015.

Blommestein, H.J. and Funke, N., (1998). Institutional Investors in the New Financial Landscape, Paris: OECD.

IE (2015). The Benefits of Insurance, Insurance Europe, Brussels.

IE (2014). European Insurance in Figures, Statistics No 50, Insurance Europe, Brussels.

IE (2013). Funding the Future: Insurers' Role as Institutional Investors, Insurance Europe, Brussels.

NBS (2015). Insurance Sector in Serbia: Report for 2014, National Bank of Serbia, Belgrade.

Vasiljević, B., (2002). Financial Market Fundamentals, Beograd: Zavet.

Davis, E.P. and Steil, B., (2001). Institutional Investors, Cambridge, MA.: The MIT Press.

Booth, P.J., et al. (1998). Modern Actuarial Theory and Practice, Boca Raton, FL.: Chapman \& Hall/CRC.

\section{FINANSIJSKA INTERMEDIJACIJA OSIGURAVAJUĆIH DRUŠTAVA}

REZIME: Zahvaljujući transformaciji društveno-ekonomskih sistema i afirmaciji tržišta kapitala u zemljama u tranziciji, uključujući zemlje regiona, pitanja pojma, uloge, značaja, načina funkcionisanja, efikasnog upravljanja portfeljom i efikasnog menadžmenta institucionalnim investitorima, dobijaju na značaju i punoj važnosti. Osiguravajuća društva doprinose privatizacionim procesima i razvoju tržišne privrede i efikasnoj alokaciji kapitala, što je posebno značajno za zemlje sa oskudicom novca i kapitala, što je upravo slučaj sa privredama zemalja regiona. Cilj istraživanja jeste analiza uloge osiguravajućih društava društava kao mobilizatora štednje $i$ investitora kao i štednje u funkciji ostvarenja ekonomskog razvoja. U radu je objašnjena struktura finansijskog sistema i uloga osiguravajućih društa$v a$, proces institucionalizacije finansijske štednje, značaj finansijske intermedijacije osiguravajućih društava, merenje prinosa i rizika investicionih plasmana osiguravajućih društava, cena rizika investiranja osiguravača $i$ značaj i karakteristike institucionalnog investiranja.

KLJUČNE REČI: finansijska intermedijacija, osiguravajuća društva, investicije. 